\title{
Characteristics and Economic Value of Tourism Services in Coastal Area of Gunungkidul Regency
}

\author{
Riesti Triyanti ${ }^{1, *}$ and Indah Susilowati ${ }^{2}$ \\ ${ }^{1}$ Master Program of Environmental Science, School of Postgraduate Studies, Diponegoro University, Semarang - Indonesia \\ ${ }^{2}$ Faculty of Economics and Business, Diponegoro University, Semarang - Indonesia
}

\begin{abstract}
The Coastal Area of Gunungkidul Regency has beautiful beaches supported by small scale fisheries activities that can attract tourists to visit. The problem of coastal management are waste overload and sectoral ego. The aims of this study are to identify socio-economics characteristics of tourists, the factors of push-pull tourists to visit, and estimate the economic value of coastal areas. Criteria of push factors tourist based on self motivation, while the pull factors based on the perception of tourists. Estimation of economic value using travel cost method. The research was conducted by survey technique. The main tourist destinations to go are to enjoy the beauty of the beach (81\%), observation of natural resources (11\%), and school assignment (8\%), with self motivation are potential of natural resources $(62 \%)$, closed distance from home (24) \%), and low cost (14\%). The perception of the tourists associated with the beach is quite beautiful $(77 \%)$ with clean and well maintained condition $(72 \%)$, but needs public facilities (38\%). Estimated economic value of coastal tourism is IDR 3.1 billion per year showed that coastal areas need to be maintained for future generations. Collaborative and transparent management of coastal resources between community and government is essential to maintain coastal tourism sustainability.
\end{abstract}

Keywords: tourism ; coastal ; socio-economics ; push-pull theory ; TCM ; Gunungkidul.

\section{Introduction}

Utilization of coastal areas has an impact on the resources, and socio-economic condition of coastal communities [1], some efforts to utilize coastal and marine resources are tourism services and small-scale fisheries. Three main reasons that support coastal areas become tourist sites, namely, various ecosystems that are interrelated in coastal areas, demand for coastal tourism has increased from year to year, and in an island nation like Indonesia, coastal tourism is a major mainstay [2].

National tourism conditions have increased from 2010 to 2016. The biggest increase occurred in 2016 at $8.4 \%$ compared to 2015 , and the increase in foreign exchange reached IDR 176 to 184 trillion. However, the direct contribution of the tourism sector to the percentage of total GDP showed a relatively stable figure in the range of 4\% [3]. In the three coastal regions of Daerah Istimewa Yogyakarta (DIY) Province, most have been developed and are intended for the development of coastal tourism, while other aspects such as cave tours and rural tourism are still minimal developed. The development of the tourism sector in DIY coastal areas is reflected in tourist visits (foreign and national). In the last five years (20122016), the average number of tourists visiting experienced an average increase of $18 \%$. In 2016, tourist visits in coastal districts DIY were sequentially dominated by Bantul Regency (52\%), Gunungkidul Regency (35\%), and Kulon Progo Regency (13\%).

The coastal area in Gunungkidul Regency extends for $\pm 70 \mathrm{~km}$ is a great potential to be developed in the coastal tourism sector. At present Gunungkidul Regency has 46 beaches spread along the southern coastline, but only 12 beaches are designated as tourism objects and continuously attract tourists [4]. The number of visitors in Coastal Area of Gunungkidul Regency increased in the last three years, from 1,6 billion in 2015 to 2,2 billion in 2017 [4]. The tourism sector in Gunungkidul Regency that will continue to grow rapidly in the coming years, the environment around the upcoming tourist attraction large enough in terms of energy consumption and waste emissions classified by tourism development. The more volume of tourists, both domestic and international, will increase emissions from greenhouse gases, especially carbon dioxide.

The coastal area of Gunungkidul Regency is a beautiful and sloping beach with a fairly large landscape and a stretch of white sand, making it an attraction to be developed into a tourist area. However, the utilization of this coastal area is expected to cover land, beach, coastal

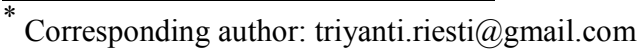


areas and waters so that all interests can be accommodated in harmony both from the economic aspect (community empowerment) and environmental sustainability aspects, so that it can be managed properly for the maximum welfare of the local community, and it will reliaze a low carbon society.

Sustainable tourism is defined as tourism development that can meet the demand of both tourists and host communities whilst preserving and improving the opportunity for future development. As a response to and reflection of the damage mass tourism brings to the ecological environment, sustainable tourism has aroused the attention of all tourism stakeholders [5]. In addition, research on the economic value of coastal areas using TCM is also carried out to determine the characteristics of tourists and the benefits of coastal areas directly for future generations ([6], [7], [8]). Therefore, the aims of this study are to identify socio-economics characteristics of tourists, the factors of push-pull tourists to visit, and estimate the economic value of coastal areas. The results of this research will provide baseline data to produce better quality tourism with lower carbon emissions and pollution in terms of transportation, accommodation, consumption, and other entertainment aspects related to tourist activities during a tour.

\section{Methodology}

The study was conducted in April to May 2018 in 6 (six) coastal areas of Gunungkidul Regency, there are: Siung Beach, Ngandong Beach, Drini Beach, Baron Beach, Ngrenehan Beach, and Gesing Beach.

Data collection was carried out by interviews using questionnaires and observation in the field. Respondents consisted of local people and visitors to beach tourism in the coastal area of Gunungkidul. The research sample was 122 respondents, which were determined based on incidental sampling technique. Data and information obtained are tabulated and then processed for analysis purposes. The analysis technique uses push-pull theory which causes tourists to come to visit and travel cost method to find out the benefits of coastal areas.

Economic valuation of coastal tourism in the Gunungkidul coastal area uses the travel cost method [9]. The first step is to find out the demand for beach tourism by using a formula:

$$
\begin{gathered}
\mathrm{Xi}=\alpha_{0}+\alpha_{1} \mathrm{TC}+\alpha_{2} \mathrm{NG}_{\mathrm{i}}+\alpha_{3} \mathrm{LV}_{\mathrm{i}}+\alpha_{4} \mathrm{~A}_{\mathrm{i}}+\alpha_{5} \mathrm{Ed}_{\mathrm{i}}+ \\
\alpha_{6} \mathrm{I}_{\mathrm{i}}+\alpha_{7} \mathrm{~S}_{\mathrm{i}}
\end{gathered}
$$

where: $\mathrm{Xi}$ is the number (frequency) of visits by individuals $\mathrm{i}$ to the beach; TC is travel costs incurred by individuals $\mathrm{i}$ to location; $\mathrm{NG}$ is number of groups (person); LV is long vacation from leaving home to go home by individuals $\mathrm{i}$; $\mathrm{A}$ is age (year) by individuals $\mathrm{i}$; Ed is education level (year) by individuals $\mathrm{i}$, I is income by individual i per year; and $\mathrm{S}$ is substitution characteristics that may exist elsewhere. In the Log-linear form this function becomes a form:

$$
\begin{aligned}
& \mathrm{LnXi}=\alpha_{0}+\alpha_{1} \operatorname{LnTC}+\alpha 2 \mathrm{LnNGi}+\alpha_{3} \mathrm{LnLV}_{\mathrm{i}}+ \\
& \alpha 4 \mathrm{LnAi}+\alpha 5 \mathrm{LnEdi}+\alpha 6 \mathrm{LnIi}+\alpha 7 \mathrm{LnSi}
\end{aligned}
$$

The next step is to calculate the economic value of coastal tourism related to the demand function.

\section{Result and Discussion}

\subsection{Characteristic of Tourist in Coastal Area of Gunungkidul Regency}

Characteristics of respondents are the most important part of a study because by knowing the characteristics of respondents we can better know the object of our research [10]. Based on the research that has been done, it is known that the various socio-economic characteristics of visitors of coastal tourism objects in the coastal area of

\begin{tabular}{|c|c|c|c|}
\hline \multicolumn{2}{|c|}{ Characteristic socio-economic } & Amount & Percentage \\
\hline \multirow[t]{2}{*}{ Gender } & Male & 60 & $49 \%$ \\
\hline & Female & 62 & $51 \%$ \\
\hline \multirow[t]{6}{*}{ Age } & $\leq 20$ & 11 & $9 \%$ \\
\hline & $21-30$ & 73 & $60 \%$ \\
\hline & $31-40$ & 21 & $17 \%$ \\
\hline & $41-50$ & 8 & $7 \%$ \\
\hline & $51-60$ & 6 & $5 \%$ \\
\hline & $\geq 60$ & 3 & $2 \%$ \\
\hline \multirow{6}{*}{$\begin{array}{l}\text { Education level } \\
\text { (year) }\end{array}$} & SD & 11 & $9 \%$ \\
\hline & SMP & 7 & $6 \%$ \\
\hline & SMU & 42 & $34 \%$ \\
\hline & D3 & 15 & $12 \%$ \\
\hline & S1 & 46 & $38 \%$ \\
\hline & S2 & 1 & $1 \%$ \\
\hline \multirow[t]{4}{*}{ Occupation } & Student & 40 & $33 \%$ \\
\hline & $\begin{array}{l}\text { Gov. } \\
\text { employees }\end{array}$ & 13 & $11 \%$ \\
\hline & $\begin{array}{l}\text { Private } \\
\text { employees }\end{array}$ & 38 & $31 \%$ \\
\hline & Entrepreneur & 31 & $25 \%$ \\
\hline \multirow{6}{*}{$\begin{array}{l}\text { Income (IDR } \\
\text { million per year) }\end{array}$} & $\leq 10$ & 13 & $11 \%$ \\
\hline & $11-20$ & 56 & $46 \%$ \\
\hline & $21-30$ & 25 & $20 \%$ \\
\hline & $31-40$ & 8 & $7 \%$ \\
\hline & $41-50$ & 6 & $5 \%$ \\
\hline & $\geq 51$ & 14 & $11 \%$ \\
\hline \multirow[t]{7}{*}{ Regional origin } & West Java & 3 & $2 \%$ \\
\hline & Central Java & 64 & $52 \%$ \\
\hline & DIY & 49 & $40 \%$ \\
\hline & East Java & 1 & $1 \%$ \\
\hline & Borneo & 1 & $1 \%$ \\
\hline & Sumatera & 2 & $2 \%$ \\
\hline & Riau Islands & 2 & $2 \%$ \\
\hline
\end{tabular}
Gunungkidul Regency (Table 1).

Table 1. Socio-economic characteristic of tourist in coastal area of Gunungkidul Regency

Source : Primary data processed (2018)

The socioeconomic characteristics of visitors in the coastal area of Gunungkidul Regency consist of gender, age, level of education, occupation, income, and regional origin. For gender of the majority of respondents data is dominated by women sex as 62 people or equivalent to $51 \%$, while male sex as many as 60 people or equivalent to $49 \%$. The female visitors dominance to visits becaused the woman's lifestyle which tends towards traveling and socialite. Lifestyle is a description of the behaviour and activities of a person in their life everyday. Now, lifestyle is a modern lifestyle, where this lifestyle occurs due to the 
influence that appears in society or the environment, thus affecting the mindset, how to act, and how to speak.

Visitors who come to the coastal area of Gunungkidul Regency based on age are known to the majority of visitors age are 21 to 30 years, with the number of data samples of visitors as many as 73 people or a percentage of $60 \%$. This age group is a productive age group. For the education level, the majority of visitors are highly educated, namely equivalent to S1 / Higher Education as many as 46 people, equivalent to $38 \%$, and for the high school education level as many as 42 people, equivalent to $34 \%$. A high level of education shown that preference of the community to visit based on the main objectives for education and refreshing. Judging from the work, visitors to the coastal area of Gunungkidul Regency were dominated by students as many as 40 people (33\%) with annual income from their parents known to be 11-20 million. The trip of students are the task of the school in the form of field trips, class holidays, practicum or research.

For the regional origin of the visitors to visit the coastal area of Gunungkidul Regency are dominated by Central Java with a percentage of $52 \%$, then DIY $40 \%$. This shows that there has been lack of promotion from the Culture and Tourism Office to present the amazing beauty of natural beaches on the coast of Gunungkidul Regency in national or international level. The peak of visitors during Eid Fitri or school holidays. According to research data, frequency of visits respondent dominated by first visits $(47 \%)$, two to five times $(34 \%)$, six to ten times $(3 \%)$, and more ten times $(16 \%)$. Some of respondents who made the first visit said they wanted to visit again because the scenery was beautiful and comfortable.

\subsection{Pull-Push Factor Tourist to Visit Coastal Area of Gunungkidul Regency}

A review of the past literature on tourist motivation indicates that the analysis of motivations based on the two dimensions of push and pull factors have been generally accepted. The concept behind push and pull dimension is that people travel because they are pushed by their own internal forces and pulled by the external forces of destination attributes. Most of the push factors which are origin-related are intangible or intrinsic desires of the individual travelers [11], [12]. Pull factors, on the contrary, are those that emerge as a result of the attractiveness of a destination as it is perceived by the travelers [13], [14]. They include tangible resources and travelers' perception and expectation such as novelty, benefit expectation and marketed image of the destination. Push factor related to motivation, and push factor related to perception. Perception and motivation can influence visitors' behavior to do tourism activities in coastal area. The result of this study shown on the Table 2. Not all motivation and perception criteria are used in this study, only a relevant criteria.
Table 2. Motivation and Perception Visitors in Coastal Area of Gunungkidul Regency

\begin{tabular}{|c|c|c|c|c|}
\hline $\mathrm{N}$ & \multicolumn{2}{|c|}{ Motivation } & \multicolumn{2}{|c|}{ Perception } \\
\hline 0 & Indicators & Percentage & Indicators & Percentage \\
\hline \multirow[t]{4}{*}{1.} & \multicolumn{2}{|c|}{$\begin{array}{l}\text { The main purpose to } \\
\text { visit }\end{array}$} & \multicolumn{2}{|c|}{ The beauty of the beach } \\
\hline & $\begin{array}{l}\text { Relaxatio } \\
\mathrm{n}\end{array}$ & $81 \%$ & $\begin{array}{l}\text { Most } \\
\text { beautiful }\end{array}$ & $12 \%$ \\
\hline & $\begin{array}{l}\text { Environm } \\
\text { ent }\end{array}$ & $11 \%$ & $\begin{array}{l}\text { Plenty } \\
\text { beautiful }\end{array}$ & $77 \%$ \\
\hline & $\begin{array}{l}\text { Personal } \\
\text { (study) }\end{array}$ & $8 \%$ & $\begin{array}{l}\text { Not } \\
\text { beautiful }\end{array}$ & $11 \%$ \\
\hline \multirow[t]{5}{*}{2.} & \multicolumn{2}{|c|}{$\begin{array}{l}\text { The reason to visit } \\
\text { coastal area (beach) }\end{array}$} & \multicolumn{2}{|c|}{ Envionmental condition } \\
\hline & $\begin{array}{l}\text { Close } \\
\text { distance }\end{array}$ & $24 \%$ & $\begin{array}{l}\text { Very well } \\
\text { maintaine } \\
\text { d }\end{array}$ & $22 \%$ \\
\hline & Low cost & $14 \%$ & $\begin{array}{l}\text { Pretty well } \\
\text { maintaine } \\
\text { d }\end{array}$ & $72 \%$ \\
\hline & $\begin{array}{l}\text { Flora and } \\
\text { fauna } \\
\text { potency }\end{array}$ & $52 \%$ & $\begin{array}{l}\text { Not } \\
\text { maintaine } \\
\text { d } \\
\end{array}$ & $6 \%$ \\
\hline & $\begin{array}{l}\text { Naturally } \\
\text { environme } \\
\text { nt }\end{array}$ & $10 \%$ & & \\
\hline 3. & - & - & \multicolumn{2}{|c|}{ Recreation facility } \\
\hline & - & - & Complete & $30 \%$ \\
\hline & - & - & $\begin{array}{l}\text { Quite } \\
\text { complete }\end{array}$ & $38 \%$ \\
\hline & - & - & $\begin{array}{l}\text { Not } \\
\text { complete }\end{array}$ & $32 \%$ \\
\hline
\end{tabular}

Source: Primary data processed (2018)

\subsection{Economic Value of Coastal Tourism in Gunungkidul Regency}

Determination the economic value of tourism based on the travel cost approach, that is the amount of money spent during a visit to the coastal area of Gunungkidul Regency. These costs include round-trip transportation costs, lodging costs, consumption costs, rent car cost at tourist sites, entrance ticket, and other costs (toilets, parking, etc.). Costs incurred by visitors to travel are used as proxies to determine the value of coastal tourism in Gunungkidul Regency [6], [7], [8], [10], [15], [16], [17]. Visitors spend more on transportation (38\%), consumption (29\%), rent car (14\%), lodging cost (12\%), entrance ticket $(4 \%)$, tourism services $(1 \%)$, and others $(2 \%)$. To know further the results of estimation of multiple linear regression and factors that influence tourism demand in the coastal area of Gunungkidul Regency can be seen in Table 3.

Table 3. Estimation of multiple linear regression estimates and factors affect tourism demand in coastal area Gungkidul Regency

\begin{tabular}{|l|c|c|c|c|}
\hline \multicolumn{1}{|c|}{ Variable } & Coefficient & $\begin{array}{c}\text { Std. } \\
\text { Error }\end{array}$ & T Stat & Sig \\
\hline Constanta & 0,245 & 1,628 & 1,505 & 0,135 \\
\hline Travel costs & & & & \\
& $-0,257$ & 0,102 & $-2,515$ & 0,013 \\
\hline
\end{tabular}




\begin{tabular}{|l|c|c|c|c|}
\hline \multicolumn{1}{|c|}{ Variable } & Coefficient & $\begin{array}{c}\text { Std. } \\
\text { Error }\end{array}$ & T Stat & Sig \\
\hline $\begin{array}{l}\text { Number of } \\
\text { groups }\end{array}$ & 0,023 & 0,047 & 0,499 & 0,619 \\
\hline $\begin{array}{l}\text { Long } \\
\text { vacation }\end{array}$ & 0,062 & 0,129 & 0,486 & 0,628 \\
\hline Age & 0,144 & 0,242 & 0,596 & 0,552 \\
\hline Education & 0,357 & 0,199 & 1,792 & 0,076 \\
\hline Income & $-0,018$ & 0,093 & $-0,196$ & 0,845 \\
\hline Substitution & $-0,143$ & 0,212 & $-0,675$ & 0,501 \\
\hline $\mathrm{R}^{2}=0,108$ \\
\hline Adjusted $\mathrm{R}^{2}=0,054$ \\
\hline $\mathrm{F}$ count $=1,982$ \\
\hline Sig F $=0,064$ \\
\hline $\mathrm{n}=122$ \\
\hline
\end{tabular}

Source: Primary data processed (2018)

From these results, if the regression equation is written is as follows:

$$
\begin{aligned}
& Y=0,245-0,257 X_{1}+0,023 X_{2}+0,062 X_{3}+ \\
& 0,144 X_{4}+0,357 X_{5}-0,018 X_{6}-0,143 X_{7}
\end{aligned}
$$

where:

$\mathrm{Y}=$ number demand of visits to coastal area Gunungkidul Regency

$\mathrm{X}_{1}=$ travel cost to coastal area Gunungkidul Regency

$\mathrm{X}_{2} \quad$ = number of groups respondent

$\mathrm{X}_{3}=$ long vacation of respondent

$\mathrm{X}_{4}=$ respondent age

$\mathrm{X}_{5} \quad=$ respondent education

$\mathrm{X}_{6}=$ respondent income

$\mathrm{X}_{7}=$ others object of tourism (substitution)

From the results of statistical estimates it can be seen that, there are several independent variables in this study that have no significant effect on the dependent variable, namely income variables and substitution variables. This variable does not have a significant effect because respondents who visited the coastal area of Gunungkidul Regency come from areas close to Gunungkidul Regency so that they do not need large income (affordable costs) other than that according to respondents, there are no other beach tourism in DIY or Central Java as good as in Gunungkidul Regency so respondents get the benefits offered by the Coastal Area of Gunungkidul Regency.

The coefficient of determination is used to test the godness-fit of the regression model. The amount of adjusted R2 is 0.054 which means that the variability of the dependent variable can be explained by the variability of the independent variable of 5.4 percent, while the remaining 94.6 percent is explained by other variables not included in the regression model. Based on the results of statistical calculations using Excel 2013, the calculated F value is 1.982 with a significance level of 0.064 . When viewed from the significant value of $\mathrm{F}$ it is obtained that the value of $\mathrm{F}$ table with $\mathrm{df} 1=7$ and $\mathrm{df} 2=122-7-1=$ 114 is 2.09 . This means that together the variable costs of travelling to coastal area of Gunungkidul Regency and others socioeconomic variables, have no significant effect on the number of visits to the coastal tourism object of Gunungkidul Regency.
Partial test is used to determine the effect of each dependent variable. Statistical $t$ test can be done by looking at and comparing $\mathrm{t}$ tables with $\mathrm{t}$ count. The value of $\mathrm{t}$ table for $\mathrm{df}=122(\mathrm{n}-\mathrm{k}=122-7=115)$ with a significance level of $5 \%$ or 0.05 is \pm 2.619 by comparing the value of $t$ with a significance level of $5 \%$ or 0.05 . All seven variables used, the test results show $t$ count $<t$ table, so that partially all variables do not affect the number of tourism requests in the coastal area of Gunungkidul Regency.

One of the aims in this study is to calculate the economic value of the coastal area of Gunungkidul Regency using economic valuations. The method used is the individual travel cost method, by calculating the value of the consumer surplus per individual per year. The regression results between the number of visits $(\mathrm{Y})$ and the independent variable produce the equation model as follows:

$$
\mathrm{Dx}=\mathrm{Qx}=\mathrm{a}-\mathrm{bP}
$$

where :

Dx : Demand visit

Qx : Number of visits

a : Constanta

b : Coefficient regression

$\mathrm{P} \quad$ : Price or travel cost

$$
\mathrm{Dx}=\mathrm{Qx}=3,622-0,257 \mathrm{P}
$$

the above equation is used to count a consumer surplus as an economic value. To calculate consumer surplus, the following equation is used:

$$
\mathrm{CS}=-\mathrm{Y} / \mathrm{b}
$$

where:

CS : Consumer surplus

Y : number demand visits to coastal area Gunungkidul Regency

$\mathrm{b}:$ coefficient regression

To obtain the total economic value of coastal area in Gunungkidul Regency, the value of the consumer surplus per individual per year is IDR $1.263,56$ multiplied by the average number of visitors in 2015-2017 that is 2.480.753 visitors, so that the total economic value of the coastal area tourism object in Gunungkidul Regency is IDR 3.134.582.871 per year.

\section{Conclusion}

The conclusion of this study is that:

1. The socioeconomic characteristics of visitors are dominated by female (51\%), productive age $21-30$ years (30\%), high education (bachelor degree) (38\%) with student employment status (33\%), and annual income IDR $11-20$ million (46\%). The regional origin of the visitor is dominated by Central Java (52\%).

2. Pull factors (motivation) of visitors to visit coastal area of Gunungkidul Regency shown that the main purpose of visits is for relaxation (81\%) and the reason to visit coastal area is to enjoy the flora and fauna potency $(52 \%)$, and the push factors (perception) of visitors to visit coastal area of Gunungkidul Regency shown that the beach are plenty beautiful $(72 \%)$, environmental condition are pretty well maintained 
$(72 \%)$, and recreational facilities are quite complete $(38 \%)$.

3. The economic value of Gunungkidul Regency coastal tourism per year is IDR 3,14 bilion with a consumer surplus per year IDR 1,3 thousands.

4. The implementation of low-carbon tourism as a whole must involve policy makers, all sectors supporting tourism, local communities, in addition to tourists as a subject to achieve better quality tourism and are expected to form a harmony between economic and social development, while still taking into account environmental aspects. Tourists are the main drivers in implementing low-carbon tourism. The application of low carbon patterns for tourists can be done through a green food diet, not using disposable tableware, tourists are encouraged to choose hotels that apply the green principle, tourists can choose to live together in the hostel so save costs and save electricity used, tourists are expected to contribute in terms of reducing waste produced, use their own shopping bags, and avoid excessive packing, besides that tourists can also choose eco-friendly tour packages.

Thanks to all respondent (visitors of beach) and chairman of Kelompok Sadar Wisata in coastal area of Gunungkidul Regency, also Marine and Fisheries Education Center (PUSDIK KKP) for financial research support.

\section{References}

1. Khairunnisa, T. Kusumastanto, A. Fahrudin. JEPI. 18, 1 (2017)

2. S. Amanah, H.N. Utami. JP. 2, 2 (2006)

3. Tourism Ministry of Republic Indonesia. Tourism Statistics for 2017. (2017)
4. Local Culture and Tourism Gunungkidul District. Tourism Statistics of Gunungkidul District 2016. (2017)

5. M. Deery, L. Jago, L. Fredline. TM. 30, 1 (2011)

6. A.R. Font. JEEM. 39, 1 (2000)

7. W. Chen, H. Hong, Y. Liu, L. Zhang, X. Hou, M. Raymond. CER. 15, 4 (2004)

8. F. Zhang, X.H. Wang, P.A.L.D. Nunes, C. Ma. ES. 11 (2015)

9. A. Fauzi. Economic of natural resources and environment. Jakarta: PT. Gramedia Pustaka Utama (2004)

10. A.J. Mateka, I. Erlinda, N. Harahap. APiSJ. 1, 1 (2015)

11. A. Beh, and B. L. Bru yere, Tourism Mgt, 28, 6, 1464 $-1471,(2007)$

12. H. Bansal, and H. A. Eiselt, Tourism Mgt, 25 (3), 387 $-396,(2004)$

13. G. Prayag, and S. Hosany, Tourism Mgt, 40, 35-45, (2014)

14. S.D. Rossi, J. A.Byrne, C. M.Pickering, and J. Reser, Geoforum, 66, 41-52, (2015)

15. G. Arabatzis, and E. Grigoroudis, V Forest Policy and Economics, 12, 3, 163-172, (2010)

16. B. Blackwell. Economic Analysis and Policy. 37, 1, 77-99, (2007)

17. L. Carr, R. Mendelshon. AMBIO: A Journal of the Human Environment. 32, 5, 353-357, (2003) 